\title{
HEMOTOXIN PRODUCTION BY THE STREPTOCOCCUS IN RELATION TO ITS METABOLISM
}

\author{
Marjorie W. Cook; Virginia Mix, \\ AND \\ ETHEL O. CULVYHOUSE \\ From the Department of Pathology and Bacteriology, University of California, \\ Berkeley, Calif.
}

As hemotoxin ${ }^{1}$ production by the streptococcus must be considered an evidence of metabolic processes, a study of this question involves a consideration of all factors, environmental and nutritional, which exert an influence on its growth. In fact, growth relationships regulate almost entirely the production of hemotoxin, for any change in the growth of the organism is reflected in the course of this production. By what process hemotoxin is formed is not known. Satisfactory evidence has been given that in the case of the streptococcus it is not an endotoxin, as bacterial extracts and preparations containing disintegrated organisms have not been found to possess hemotoxic properties. There has been considerable difference of opinion as to whether hemotoxin is produced as an entity, that is, whether it exists free from the organism. Experiments in which filtrates of hemotoxic cultures have been tested for their lytic properties have given variable results, as reported by different investigators. In a large number of cases, hemotoxic filtrates have not been obtained. However, according to Besredka, ${ }^{2}$ M'Leod, ${ }^{3}$ and others, if the filtrate is prepared from a very active growth on a medium containing a large percentage of serum, from 20 to $50 \%$, it possesses hemotoxic properties, although the concentration of hemotoxin of the filtrate is never as great as that of the original culture. These results establish the fact that hemotoxin under certain conditions may exist free from bacteria.

No conclusive evidence has been obtained in regard to the nature of hemotoxin, whether it is an enzyme, a secretion or excretion product. Extensive studies have been made of the chemical and

Received for publication Sept. 25, 1920.

1 In view of our own experiments and in conformity with the usage of certain other authors (Sachs and Pribram), we prefer to refer to the blood corpuscle destroying substances in bacteria as hemotoxins rather than as hemolysins, since they differ markedly in their mode of action from the better defined hemolysin of normal and immune serums.

2 Ann. de l'Inst. Pasteur, 1901, 15, p. 880.

s J. Path. and Bacteriol., 1911-12, 16, p. 321. 
physicochemical properties. It is known that hemotoxin is associated with the globulins of the medium, but as it has not been obtained in a pure state, its exact chemical nature has not been determined. As regards its physicochemical properties studies have been made of its thermolability, its dialyzing properties, the effect of acids, bases, and salts, as well as its behavior on inactivation and capabilities of reactivation. Concerning the immunologic properties of hemotoxin, there is also a difference of opinion, but the majority of workers have not been able to demonstrate antigenic properties, as satisfactory evidence of the formation of antihemotoxins has not been obtained.

A complete study of streptococcus hemotoxin would involve a consideration of all these phases of the subject. Of chief importance for the present work, however, is a study of the factors that govern the formation of hemotoxin in the living streptococcus culture. Among these factors are to be considered especially the influence of the composition of medium, the rate of growth, the relation between the presence of fermentable sugars and formation of hemotoxin and the effect of the metabolic products of the culture. Of the last, the question of the effect of acidity on hemotoxin production requires especial study. As virulence and growth relationships are closely connected, it is also of interest to determine whether passage of a culture through animals causes any variation in its hemotoxic properties. Experimental work on these phases of the subject will be reported.

\section{EXPERIMENTAL PROCEDURE}

The entire study was made on Streptococcus pyogenes " $\mathrm{H}$," which was isolated from the lung in a fatal case of bronchopneumonia with empyema and endocarditis. This strain corresponds to culture 136 in a series of streptococci obtained in an investigation of pneumonia by Cole and MacCallum, ${ }^{4}$ and it has further served as the basis of an extensive study of experimental empyema in rabbits by Gay and Stone. ${ }^{5}$ For determinations on hemotoxin production two types of this culture were used-one that had been kept on artificial medium since the primary isolation and was called the laboratory strain, the other, a passage strain, that was injected intrapleurally into rabbits and recovered in the pleural exudate. Record of the type used is made in all experiments. In the present investigation no attempts were made to obtain hemotoxic filtrates; only living cultures were used.

4 Jour. Am. Med. Assn., 1918, 70, p. 1146.

J. Infect. Dis., 1920, 26, p. 265. 
TECHNIC OF THE TITRATION OF HEMOTOXIN

All titrations of hemotoxin were made with sterile tubes, pipets, etc., to maintain the purity of the streptococcus culture. The corpuscles used were rabbit corpuscles, obtained by bleeding from the marginal ear vein into $0.85 \%$ sodium chloride containing $1 \%$ of sodium citrate. The corpuscles were washed 3 times in $0.85 \%$ sodium chloride and made up to a $1 \%$ suspension in beef infusion broth. To $0.5 \mathrm{cc}$ of suspension were added amounts of culture varying from 0.005 to $0.5 \mathrm{cc}$. The volume was made up to $1 \mathrm{c} \mathrm{c}$ with broth and the mixtures incubated at $37 \mathrm{C}$. for 2 hours. During the first hour of incubation the tubes were shaken frequently to insure thorough mixing. The degree of lysis was observed at the end of the incubation period and the titer was expressed as follows:

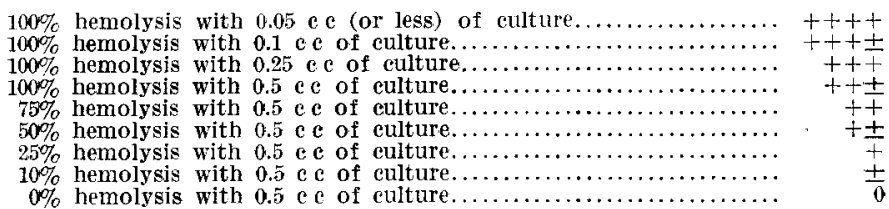

THE EFFECT OF THE MEDIUM ON HEMOTOXIN PRODUCTION

The question of the optimum composition of a medium for hemotoxin production has been studied by a large number of investigators. The conclusions made are uniform in that the maximum production has been found to occur in meat infusion broth containing a fairly high percentage of animal fluid, usually serum, although hydrocele and ascitic fluid have been found to be equally efficacious. It is generally conceded that a broth containing from 10 to $50 \%$ of horse serum furnishes the most favorable conditions for hemotoxin production (Lyall, ${ }^{6}$ M'Leod, ${ }^{3}$ Nakayama, ${ }^{7}$ Von Hellens ${ }^{8}$ ). Walbum ${ }^{9}$ lays particular emphasis on peptone. He considers that peptone is an essential factor and may be looked on as a prolysin. Lyall obtained better results with $2 \%$ than with $1 \%$ peptone. Sugars, particularly those that are easily fermented by the streptococcus, have been found by all workers to exert an inhibitory action on the production of hemotoxin.

6 J. Med. Res., 1914, 30, p. 315.

7 J. Infect. Dis., 1919, 25, p. 509.

8 Centralbl. f. Bakteriol., O. I, 1913, 68, p. 602.

Z Ztschr. f. Immunitätsf., O., 1909, 3, p. 70. 
In the present work beef infusion broth containing $1 \%$ of peptone and $0.5 \% \mathrm{NaCl}$ was used as a basis for all mediums. No experiments were carried out to determine the effect of varying the concentration of peptone. Hemotoxin production was studied in plain beef infusion broth, in broths containing serum, carbohydrates and alcohols.

Exper. 1. Preliminary Test on Hemotoxin Production in Various Mediums. -Plain beef infusion broth, broth containing $5 \%$ rabbit serum, ${ }^{10}$ broth containing $1 \%$ glucose, and broth containing $5 \%$ serum and $1 \%$ glucose were inoculated with an 18-hour plain broth culture of the laboratory strain. The cultures were incubated for a period of 24 hours. Titrations of hemotoxin were made at the time of inoculation and at intervals of $1,2,4,6,8,10,12$, 16 and 24 hours. The results are given in table 1 , which shows that of the mediums tested, serum broth furnished the most favorable conditions for hemotoxin production. In the plain broth and serum glucose broth cultures, hemotoxin appeared later and in general was present in lower concentrations, while in glucose broth there was no hemotoxin demonstrable. In serum broth, hemotoxin was present in fairly high concentrations in a 1-hour growth, while the maximum production was reached at the fourth hour and persisted through the tenth hour. In plain broth, hemotoxin did not appear until the eighth hour, and it was then produced only in slight amounts. The maximum point of production in plain broth occurred at the tenth hour after which hemotoxin rapidly decreased. At no time did the concentration of hemotoxin in plain broth reach a point which was more than one-tenth as great as that in serum broth. In serum glucose broth the time of maximum production occurred at the tenth hour, as in plain broth. The concentration of hemotoxin was higher than in plain broth and lower than in serum broth.

TABLE 1

Hemotoxin Production in Various Mediums

\begin{tabular}{c|c|c|c|c}
\hline \hline $\begin{array}{c}\text { Age of } \\
\text { Culture }\end{array}$ & $\begin{array}{c}\text { Plain } \\
\text { Broth }\end{array}$ & $\begin{array}{c}5 \% \text { Serum } \\
\text { Broth }\end{array}$ & $\begin{array}{c}1 \% \text { Glucose } \\
\text { Broth }\end{array}$ & $\begin{array}{c}\text { 5\% Serum and } \\
\text { 1\% Glueose Broth }\end{array}$ \\
\hline At inoculation & 0 & 0 & 0 & 0 \\
1 hour & 0 & +++ & 0 & 0 \\
2 hours & 0 & +++ & 0 & 0 \\
4 hours & 0 & ++++ & 0 & ++ \\
8 hours & 0 & ++++ & 0 & +++ \\
10 hours & + \pm & ++++ & 0 & ++++ \\
12 hours & ++ \pm & ++++ & 0 & ++ \pm \\
$\mathbf{1 6}$ hours & ++ & +++ \pm & 0 & +++ \\
24 hours & + \pm & ++ \pm & 0 & + \pm \\
\hline
\end{tabular}

These results agree fairly well with those of other workers. Sekiguchi ${ }^{11}$ found the first appearance of hemotoxin in a 1 to 2-hour growth of a serum broth culture. According to Lyall ${ }^{6}$ hemotoxin was not observed earlier than 3 hours, and, according to M'Leod, ${ }^{3}$

\footnotetext{
to Rabbit serum was used in the early part of the work, but later was replaced by horse serum, comparative tests on the two showing no difference in their hemotoxin producing properties.

11 J. Infect. Dis., 1917, 21, p. 475.
} 
not earlier than 10 hours. The time of maximum production was found by Sekiguchi to be from 15 to 18 hours, by Von Hellens ${ }^{8} 14$ hours, by Stevens and Koser ${ }^{12} 6$ to 10 hours and by de Kruif and Ireland ${ }^{13} 7$ to 8 hours. All authors observed a gradual decrease beginning from 12 to 18 hours, with a final disappearance of hemotoxin in 48 to 72 hours. It is probable that the differences in the results of various investigators are due to the use of mediums of varying composition.

As in this preliminary experiment glucose was found to inhibit hemotoxin, a further test was made on the effect of this sugar and several other carbohydrates that are fermented by the streptococcus, of starch which is not digested by the " $\mathrm{H}$ " strain, and of the alcohols, glycerol and mannitol.

Exper. 2. Hemotoxin Production in Mediums Containing Various Carbohydrates and Alcohols. - A series of mediums containing glucose, levulose, lactose, starch, salicin, glycerol, and mannitol in concentration of $1 \%$, as well as control preparations of plain broth and $5 \%$ serum broth, were inoculated in amounts of $10 \mathrm{cc}$ with $0.1 \mathrm{cc}$ of an 18-hour plain broth culture of pleural fluid 204. The cultures were incubated 24 hours, and portions removed at the beginning of incubation and at intervals of $4,8,12$, and 24 hours, for tests on hemotoxin production. $P_{H}$ determinations were also made to correlate the conditions of hemotoxin production with acidity production. The results are given in table 2 .

It will be noticed in table 2 that as in exper. 1 , the greatest production of hemotoxin occurred in a serum broth culture. In this experiment, the mediums next in order of efficiency were plain broth and glycerol broth. A retardation and decrease of hemotoxin production, as compared with serum and plain broth cultures, were observed in all mediums containing carbohydrates which are fermented by the streptococcus. The most marked inhibition occurred in cultures containing glucose and levulose. In lactose, starch, and mannitol mediums, hemotoxin production was almost equal to that in plain broth, while in salicin, a moderate amount of hemotoxin was formed. It will be noted that in this experiment the inhibition exerted by glucose was less marked than in exper. 1. This apparent discrepancy is probably due to the fact that the laboratory strain of streptococcus was used in exper. 1, while in exper. 2 the passage strain was used. Later experiments show distinct differences in results obtained with the two strains. Observation of the hydrogen-ion concentration of the

12 J. Exper. Med., 1919, 30, p. 539.

19 J. Infect. Dis., 1920, 26, p. 285. 


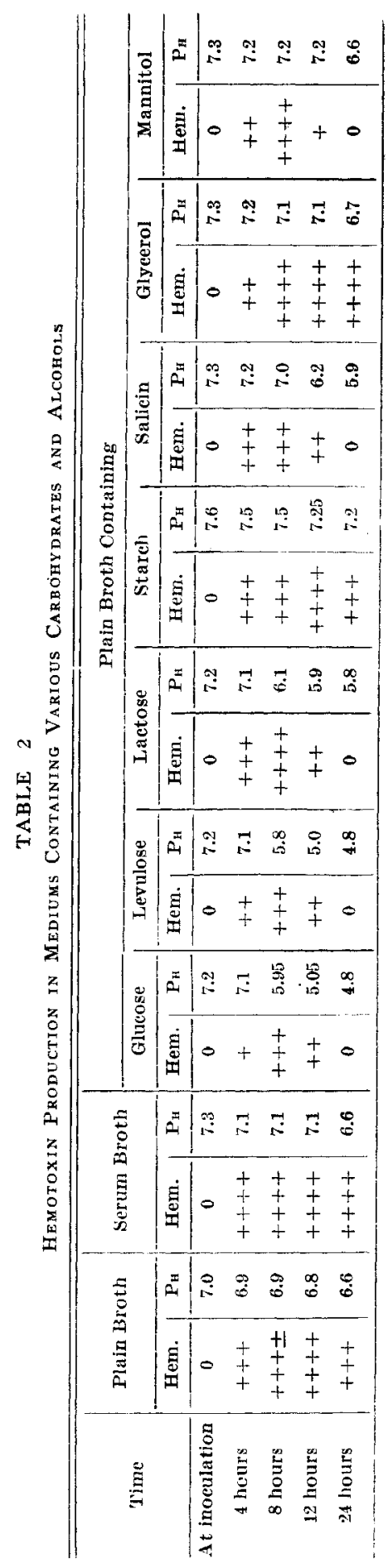


various mediums at the intervals recorded shows that hemotoxin was produced in smallest amounts when the acidity of the culture increased most rapidly.

Repetition of these tests did not give entirely constant results. Variations have been observed by a number of investigators. Lyall ${ }^{6}$ states that the interference by sugars is not always uniform, but that glucose is most constant in its inhibiting properties. Stevens and Koser ${ }^{9}$ found that glucose, maltose, and saccharose constantly inhibited, that lactose and salicin were inconstant. In the present work it was found that while there were differences in the extent to which glucose inhibited hemotoxin production, nevertheless a certain amount of inhibition was always exerted by this sugar, if used in a concentration of $1 \%$. However, if lower percentages were used practically no inhibition was present, as will be seen in exper 3 .

Exper 3. The Effect of Varying the Percentage of Glucose in the Medium Used for the Production of Hemotoxin.-Titrations of hemotoxin production were made on 6-hour cultures of streptococcus grown in plain broth containing $1,0.1$, and $0.01 \%$ of glucose, and in serum broth containing the same percentages of glucose. Control titrations on cultures in plain and serum broths containing no glucose were also made. For inoculation of these cultures $0.1 \mathrm{c} \mathrm{c}$ of a plain broth culture from pleural fluid 590 was added to $10 \mathrm{cc}$ of each of the above mediums. The results were:

\begin{tabular}{ccc}
\hline Percentage of & Plain Glucose & Serum Glucose \\
Glucose & Broth & Broth \\
1.0 & + & +++ \\
0.1 & ++ & ++++ \\
0.01 & +++ & ++++ \\
0.0 & +++ & $+++\cdots$
\end{tabular}

It is evident that inhibition by glucose is not an absolute factor. It varies approximately with the concentration and is counteracted by the presence of serum. These results indicate that hemotoxin production or the lack of hemotoxin production in mediums containing glucose probably depends on the interaction of a number of influences in the growing culture, varying conditions of equilibrium among the several components producing varying results.

The mechanism of the inhibition of hemotoxin production by sugars is a question which has been the subject of much investigation. Kuhn ${ }^{14}$ has suggested that inhibition may be due to three factors: 1 . A protein sparing action; 2 . the prevention of the formation of a hemolytic ferment; 3. an injury to the activity of a hemolytic ferment. Of

14 Centralbl. f. Bakteriol,, O., I, 1912, 63, p. 97. 
these, the two last would depend on the effect of acids formed. Stevens and Koser ${ }^{12}$ conclude that numerous interacting factors "affect streptolysin in the presence of fermented sugars. The principal action is the change in the metabolism of the streptococcus by which more carbohydrate and less protein is utilized; although the growth is much increased, there is proportionately less hemolysin. The acid developed in these cultures not only lessens the vitality of the growing organism and so lessens proteolysis, but is destructive to hemolysin at incubator temperature."

In considering the mechanism of inhibition by sugars, all further work has been confined to the action of glucose, as this sugar possesses the most marked and constant inhibiting properties. Study of the question follows the lines suggested by other workers, namely, the effect of acidity production and the accumulation of metabolic products, the relationship between rate of growth and hemotoxin production, the equilibrium between carbohydrate and protein metabolism in cultures which produce hemotoxin as compared with that of cultures in which hemotoxin production is inhibited. In connection with the last factor, the question of virulence has been found to be of some importance to hemotoxin production.

Before beginning an intensive study of these phases of the subject, it seemed advisable to determine whether the action of glucose was due to an inhibition of hemotoxin production in the living culture or whether the inhibitory influence was also operative in interfering with the lytic action of hemotoxin already formed.

Exper. 4. The Effect of Adding Glucose in Varying Concentration to Hemotoxin Titration Tubes.-To a number of tubes each containing $0.25 \mathrm{cc}$ of a 12-hour culture of streptococcus grown in 5\% serum broth varying amounts of glucose were added; $0.5 \mathrm{cc}$ of a suspension of corpuscles and broth to make a total of $1 \mathrm{cc}$ were added to each tube. The results after incubation were:

\begin{tabular}{|c|c|c|}
\hline Control & \begin{tabular}{l}
\multicolumn{2}{c}{ Glucose } \\
0.005 per cent \\
0.01 per cent \\
0.05 per cent \\
0.1 per cent \\
0.5 per cent \\
1.0 per cent \\
2.5 per cent \\
0
\end{tabular} & $\begin{array}{l}\text { Hemolysis } \\
++++ \\
++++ \\
++++ \text { change to purple color } \\
++++ \text { change to purple color } \\
++++ \text { change to purple color } \\
++++ \text { change to purple color } \\
++++ \text { change to purple color } \\
++++\end{array}$ \\
\hline
\end{tabular}

A further control on the possible interfering action of glucose in the actual hemolytic test was made by exposing red cells to various concentrations of glucose before using them in the hemolytic test. 
Exper. 5. The Effect of Suspending Corpuscles in Glucose Previous to Their Use in the Hemolytic Test.-Corpuscles which had been washed 3 times in $0.85 \% \mathrm{NaCl}$ were treated as follows: Portion 1 was made up to a $1 \%$ concentration in $\mathrm{NaCl}$ containing $1 \%$ glucose, and portion 2 was made up to a $1 \%$ concentration in $\mathrm{NaCl}$ containing $10 \%$ glucose. Both portions were allowed to stand on ice for 16 hours, were then centrifugalized, and the corpuscles of each portion divided into 2 parts. The first part of each was washed 3 times in $\mathrm{NaCl}$ to remove all traces of glucose; the second part was not given further treatment. All four portions were made up to a $1 \%$ concentration in broth. The resulting suspensions, as well as a suspension of corpuscles prepared in the usual manner and used as a control, were added to a 5 -hour culture of pleural fluid 4 in serum broth. The results were identical, and it is evident that glucose does not interfere with the lytic action of a hemotoxin once formed. The inhibition by glucose in cultures of streptococcus must, therefore, be due to its influence on the formation of hemotoxin.

\section{THE EFFECT OF THE PRODUCTS OF GROWTH OF A GLUCOSE CULTURE ON HEMOTOXIN PRODUCTION}

Having narrowed down the possibilities of inhibition of the hemotoxic activities of the streptococcus by glucose to its effect on the production of hemotoxin, consideration must be given to the various possible factors, previously mentioned, which may influence the formation of hemotoxin. Attention will first be given to the question of the influence on hemotoxin of the metabolic products of a glucose culture.

The time and rate of decrease of hemotoxin production in a glucose culture suggest that the accumulation of metabolic products may have a direct bearing on the inhibition of hemotoxin production, for hemotoxin in glucose cultures begins to diminish at approximately the time at which the lowering of the $P_{H}$ of the culture indicates the presence of significant amounts of metabolic products, and ceases entirely before the maximum acidity is reached. To determine whether the inhibition of hemotoxin production may be ascribed to the presence of metabolic products by discovering whether removal of the metabolic products is followed by a resumption of hemotoxin production, organisms that were grown in glucose mediums were separated from the medium by centrifugation at a time when inhibition of hemotoxin production was complete. These organisms were then washed free from any traces of medium and resuspended in fresh mediums. Similar procedures were carried out with plain and serum broth cultures to control the possibility that the manipulations of the experiment had decreased hemotoxic activities. 
Exper. 6. The Effect of the Removal of Metabolic Products on Hemotoxin Production.-Ten c c amounts of 12-hour cultures in plain, serum, and glucose broth, prepared as usual from pleural fluid 590, were centrifugated, and the supernatant fluids were removed. The sedimented organisms were washed 3 times in plain broth and resuspended in $2 \mathrm{cc}$ of plain broth. This constituted a concentration of the culture 5 times. To $0.1 \mathrm{cc}$ portions of each of these suspensions were added $0.4 \mathrm{cc}$ amounts of plain, serum, and glucose broth, thus giving resultant suspensions that contained the same numbers of organisms as the original cultures. Hemolysis tests were made on these suspensions and on the supernatant fluids. Control tests were also made on portions of the cultures which were not centrifugated and on uninoculated portions of the mediums. The results of these tests are given in table 3 .

TABLE 3

The Effect of Resuspending Centrifugated Cultures in Various Mediums

\begin{tabular}{|c|c|c|c|}
\hline Material Tested for Hemotoxin & Amount & Medium Added & Hemolysis \\
\hline 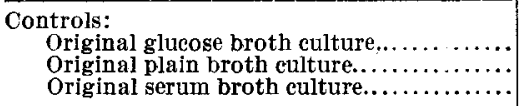 & $\begin{array}{l}0.5 \mathrm{cc} \\
0.5 \mathrm{c} \mathrm{c} \\
0.5 \mathrm{c} \mathrm{c}\end{array}$ & $\begin{array}{l}0 \\
0 \\
0\end{array}$ & $\begin{array}{l}0 \\
++++ \\
++++\end{array}$ \\
\hline 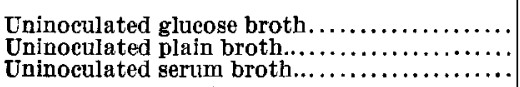 & $\begin{array}{l}0.5 \mathrm{cc} \\
0.5 \mathrm{c} \mathrm{c} \\
0.5 \mathrm{ec}\end{array}$ & $\begin{array}{l}0 \\
0 \\
0\end{array}$ & $\begin{array}{l}0 \\
0 \\
0\end{array}$ \\
\hline 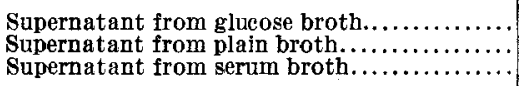 & $\begin{array}{l}0.5 \mathrm{cc} \\
0.5 \mathrm{c} \mathrm{c} \\
0.5 \mathrm{c} \mathrm{c}\end{array}$ & $\begin{array}{l}0 \\
0 \\
0\end{array}$ & $\begin{array}{l}0 \\
0 \\
0\end{array}$ \\
\hline 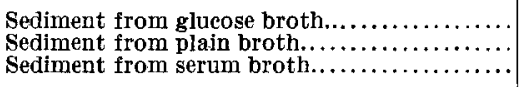 & $\begin{array}{l}0.1 \mathrm{ec} \\
0.1 \mathrm{c} \mathrm{c} \\
0.1 \mathrm{ec}\end{array}$ & $\begin{array}{l}0.4 \mathrm{c} \text { c plain broth } \\
0.4 \mathrm{c} \text { c plain broth } \\
0.4 \mathrm{c} \text { c plain broth }\end{array}$ & $\begin{array}{l}++ \\
++ \\
+++\end{array}$ \\
\hline 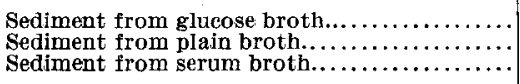 & $\begin{array}{l}0.1 \mathrm{c} \mathrm{c} \\
0.1 \mathrm{c} \mathrm{c} \\
0.1 \mathrm{c} \mathrm{c}\end{array}$ & $\begin{array}{l}0.4 \mathrm{c} \text { c serum broth } \\
0.4 \mathrm{c} \text { c serum broth } \\
0.4 \mathrm{c} \text { c serum broth }\end{array}$ & $\begin{array}{l}+++ \\
+++ \\
++++\end{array}$ \\
\hline 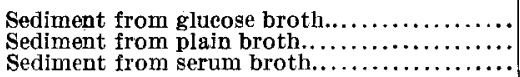 & $\begin{array}{l}0.1 \mathrm{cc} \\
0.1 \mathrm{c} \mathrm{c} \\
0.1 \mathrm{c} \mathrm{c}\end{array}$ & $\begin{array}{l}0.4 \text { c c glucose broth } \\
0.4 \text { c c glucose broth } \\
0.4 \text { c e glucose broth }\end{array}$ & $\begin{array}{c}0 \\
++ \\
+++\end{array}$ \\
\hline
\end{tabular}

It appears that a glucose culture which is incapable of hemotoxin production at the period of 12 hours' growth, recovers hemotoxic properties to some extent when the organisms are removed from the surrounding medium and resuspended in medium which has not inhibiting properties on hemolysis, that is, in plain and serum broth. The increase in hemotoxic properties is most marked in the serum broth suspension. No lysis occurred in the portion of glucose culture resuspended in glucose broth. Tests on the hemotoxic properties of plain and serum broth cultures, which were subjected to the same treatment as the glucose broth culture, showed in the case of the plain broth culture that the sediments resuspended in plain broth and in serum broth were slightly less hemotoxic than the original culture, while the sediment from the serum broth culture was as active as the original cul- 
ture when resuspended in serum broth but less active in plain broth. This would indicate that the manipulation of the culture involved in centrifugation lessened the hemotoxic activity of the organisms to some extent. Sediments from plain and serum broth cultures showed considerable activity when suspended in glucose broth. These results correspond fairly closely with those of exper. 4 in which the addition of glucose to cultures in which hemotoxin was already active caused no diminution of the hemotoxic properties. It is possible that the slight inhibition in the glucose suspensions of organisms grown in plain and serum broth in this experiment may be due to the lessening of hemotoxic activity due to centrifugation, which is manifest in all suspensions. No hemotoxin was present in any of the supernatant fluids. A repetition of this experiment gave the same results with the exception that the serum broth culture could not be completely sedimented by centrifugation, and the resultant supernatant fluid, as would be expected, was hemotoxic.

A number of points in regard to hemotoxin production by the streptococcus are brought out by this experiment, namely, that hemotoxin is not present free in the mediums used, as the supernatant fluids were not hemotoxic; and that hemotoxin is injured to some extent by centrifugation. This last detail is confirmed by the work of Robinson and Meader. ${ }^{15}$ The most significant fact is, however, that hemotoxic properties can be restored to a culture from which all hemotoxic properties have disappeared by removing the metabolic products. One must assume from this that the inhibition of lysis in glucose culture is due in a certain degree to degradation products in the medium. As a much longer time is required in plain and serum broth cultures for inhibition of hemolysis to occur, and as the $P_{\mathrm{H}}$ of these cultures decreases much less rapidly than in glucose, it is natural to assume that the acids formed in a glucose medium may be among the chief factors responsible for inhibition.

THE IMPORTANCE OF ACIDITY AS A FACTOR IN CAUSING INHIBITION OF HEMOTOXIN PRODUCTION IN GLUCOSE CULTURES

This question has been made the subject of investigation by many workers, as the possibility that a cause and effect relationship may exist between an increase in acidity and decrease in hemotoxin is one which readily suggests itself. In considering this subject a dis-

15 Proc. of Soc. of Amer. Bacteriol., 1919. Abst. Bacteriol, 1920, 4, p. 17. 
tinction should be made between the effects of the initial acidity of the medium and of the acidity produced by the culture growing in glucose. The latter phase of the subject is the one suggested by the results obtained in exper. 6 , but before entering into this question in detail mention should be made of the importance of the initial reaction to hemotoxin production.

According to the observations of Lyall, ${ }^{6}$ Stevens and Koser, ${ }^{12}$ Robinson and Meader, ${ }^{15}$ hemotoxin may be produced in mediums having a fairly wide range of initial acidities. Lyall reports that hemotoxin production does not vary greatly in mediums of reactions varying from +2 to -2 . Beyond these limits no hemotoxin is produced. Robinson and Meader place the limits of hemotoxin production between $P_{H} 7.2$ and 5.3. Stevens and Koser found that in mediums, the $P_{H}$ of which was decreased before inoculation by the addition of lactic. acid, the growth of the streptococcus and the hemolysis produced were proportional to the $\mathrm{P}_{\mathrm{H}}$. All workers report scanty or no growth in cultures beyond the range of acidity or alkalinity at which hemotoxin is formed and consider that the initial acidity of a medium affects hemotoxin production only in so far as it affects growth.

An experiment carried out with strain " $\mathrm{H}$ " confirmed the results of others.

Exper. 7. The Effect of the Initial Acidity on Hemotoxin Production.A series of tubes of plain broth varying in $\mathrm{P}_{\mathrm{H}}$ from 8.35 to 5.05 was inoculated with an 18-hour plain broth culture of pleural fluid 1088. After 6 hours, growth was observed macroscopically, and titrations of hemotoxin production were made. The results follow:

\begin{tabular}{|c|c|c|c|}
\hline$\cdot$ & $\begin{array}{c}\text { Intial } \mathbf{P}_{\mathbf{H}} \\
5.05 \\
5.35 \\
5.85 \\
6.15 \\
6.4 \\
6.9 \\
7.3 \\
7.55 \\
7.9 \\
8.1 \\
8.35\end{array}$ & $\begin{array}{c}\text { Growth } \\
0 \\
0 \\
0 \\
+ \\
++ \\
++++ \\
++++ \\
++++ \\
++++ \\
++++ \\
++++ \\
++++\end{array}$ & $\begin{array}{c}\text { Hemolysis } \\
0 \\
0 \\
0 \\
+ \pm \\
++ \\
++++ \\
++++ \\
++++ \\
++++ \\
++++ \\
++++\end{array}$ \\
\hline
\end{tabular}

It is evident that the initiation of the formation of hemotoxin may be entirely prevented by a high hydrogen-ion concentration, but the results also indicate, as has been suggested by others, that the inhibition is due to inhibition of growth and that hemotoxin production 
is probably only indirectly affected. Hemotoxin is actively formed by cultures of $P_{H}$ ranging from 6.9 to 8.35 .

The second phase of the subject has to do with the action of the acids produced by growing culture. That hemotoxin usually disappears as acidity increases is an established fact, but whether the loss of hemotoxin is caused by the accumulation of acids or the two phenomena are merely coincident is not definitely known. There is considerable difference of opinion on this subject. Sekiguchi ${ }^{11}$ assumes that hemotoxin formation is not hindered by the produced acids, since in his work "the acid and hemolysis curves do not bear the proper relation to each other." Sachs ${ }^{16}$ observed a simultaneous increase in acidity and decrease in hemotoxin, but questioned any direct effect of acidity since a daily neutralization of acid formed in his cultures did not increase hemolysis. This argument would hardly appear to be valid in view of the large amounts of acid which are formed in a day and the ample time before neutralization for these acids to act on the hemotoxin. Lyall ${ }^{6}$ calls attention to the fact that mere increase in acidity cannot be considered to be solely responsible for inhibition of hemotoxin since the inhibition in various sugar mediums is not absolutely proportional to the amounts of acid formed. Tubes showing the same amount of acid gave at the same time different concentrations of hemotoxin. This fact, together with the observation that in his experiments glucose alone exerted a constant inhibition, caused Lyall to advance the opinion that it is the kind rather than the amount of acid which is important. He showed that the acids formed as a result of the growth of the streptococcus have a different effect than HCl. Stevens and Koser ${ }^{12}$ think that the acidity of a culture acts through growth inhibition, thus preventing the formation of hemotoxin, and also through a destruction of the hemotoxin already formed. Using hemolytic filtrates they showed that the effect of acid on the hemolysin was to destroy it, as sterile hemolytic filtrates incubated in various strengths of acid lost a large part of their hemolytic properties.

In the present work, attempts to show whether a causal relationship exists between acidity production and the inhibition of hemotoxic properties of a culture have taken the following lines:

1. Neutralization of acidity in the growing culture, (a) by the addition of phosphates, (b) by the addition of alkali.

16 Ztschr. f. Hyg, u. Infecktionskr., 1909, 63, p. 463. 
2. Neutralization of the acidity of a filtrate of a culture from which hemotoxin has disappeared, and reinoculation of the neutralized filtrate with a fresh culture.

Exper. 8. The Effect on Hemotoxin Production of the Addition of Dipotassium Phosphate to Glucose Cultures.-To beef infusion broth containing $1 \%$ glucose was added, in one series, $1 \%$ of $\mathrm{K}_{2} \mathrm{HPO}_{4}$ and in a second series $2 \%$ of $\mathrm{K}_{2} \mathrm{HPO}_{4}$. Plain broth was also made up to the same concentration with phosphate, to control the effect of the phosphate itself on hemotoxin. Cultures from pleural fluid 4 were planted in these mediums in the proportion of $0.2 \mathrm{cc}$ of culture to $10 \mathrm{cc}$ of medium. Cultures were also made in glucose and plain broth containing no phosphate. All mediums were adjusted to approximately the same $P_{H}$ before inoculation. Lysis titrations and $P_{H}$ determinations were made on all cultures and on an uninoculated portion of each medium immediately after inoculation and at intervals of 6 and 12 hours. The results are given in table 4 .

TABLE 4

Results of Lysis Titrations and $P_{H}$ Determinations

\begin{tabular}{|c|c|c|c|c|c|c|}
\hline \multirow[t]{2}{*}{ Culture } & \multicolumn{2}{|c|}{$\begin{array}{l}\text { Immediately } \\
\text { After Inocu- } \\
\text { lation }\end{array}$} & \multicolumn{2}{|c|}{$\begin{array}{l}\text { After } \\
6 \text { Hours } \\
\text { Incubation }\end{array}$} & \multicolumn{2}{|c|}{$\begin{array}{l}\text { After } \\
12 \text { Hours } \\
\text { Incubation }\end{array}$} \\
\hline & $P_{H}$ & Hemolysis & $P_{n}$ & Hemolysis & $\mathrm{P}_{\mathrm{H}}$ & Hemolysis \\
\hline $\begin{array}{l}\text { Glucose broth containing } 1 \% \text { phosphate.. } \\
\text { Glucose broth containing } 2 \% \text { phosphate.. } \\
\text { Glucose broth (no phosphate)............. }\end{array}$ & $\begin{array}{l}7.4 \\
7.4 \\
7.4\end{array}$ & $\begin{array}{l}0 \\
0 \\
0\end{array}$ & $\begin{array}{l}7.2 \\
7.3 \\
6.4\end{array}$ & $\begin{array}{c}+++ \pm \\
+ \\
+++\end{array}$ & $\begin{array}{l}6.4 \\
7.2 \\
5.2\end{array}$ & $\begin{array}{c}++++ \\
+++ \\
0\end{array}$ \\
\hline $\begin{array}{l}\text { Plain broth containing } 1 \% \text { phosphate..... } \\
\text { Plain broth containing } 2 \% \text { phosphate..... } \\
\text { Plain broth (no phosphate).............. }\end{array}$ & $\begin{array}{l}7.4 \\
7.4 \\
7.4\end{array}$ & $\begin{array}{l}0 \\
0 \\
0\end{array}$ & $\begin{array}{l}7.3 \\
7.3 \\
6.8\end{array}$ & $\begin{array}{l}++++ \\
+++t \\
++++\end{array}$ & $\begin{array}{l}7.25 \\
7.3 \\
6.6\end{array}$ & $\begin{array}{l}+++t \\
+++t \\
++++\end{array}$ \\
\hline
\end{tabular}

Titrations of the uninoculated medium gave no change in $\mathrm{P}_{\mathrm{H}}$ and no evidence of lysis at any time.

A repetition of this experiment gave corresponding results. Evidently, the maintenance of an approximately neutral reaction in a glucose culture causes hemotoxin to persist for a longer time than in a culture in which the $\mathrm{P}_{\mathrm{H}}$ decreases. Glucose culture containing $1 \%$ and $2 \%$ of phosphate gave strong hemolysis with a 12 -hour growth, whereas glucose cultures without phosphate showed no hemolysis at this time. The concentration of hemotoxin in the $2 \%$ phosphate glucose culture is difficult to explain as the growth was good in this tube at both times the test was performed. Moreover, a 2\% concentration of phosphate in plain broth gave the same titer of hemotoxin as tubes containing $1 \%$ and no phosphate. Phosphate itself, therefore, cannot be considered to have any direct effect on hemolysis. The prevention of an appreciable increase in acidity must be responsible for prolonging the action of hemotoxin. These results would indicate 
that acidity must be considered as a factor concerned in the inhibition of hemotoxin by glucose.

In this experiment the action of phosphate was continuous during the growth of the culture, and it is probable that hemotoxin was almost entirely protected from the action of acid. In the next experiment, it was proposed to neutralize the acids formed in a glucose culture at frequent intervals, making the reaction correspond to that of a serum culture of the same age in which active hemotoxins were present. In connection with this, at the same intervals, acid was added to a serum culture to approximate as closely as possible the conditions in the glucose culture. The effect on hemolysis in both cultures was observed. Theoretically, it would seem possible that a glucose culture kept at the $\mathrm{P}_{\mathrm{H}}$ of a serum culture might also follow to a certain extent the hemotoxin production of a serum culture, and that the serum culture in which the $\mathrm{P}_{\mathrm{H}}$ was made to correspond to that of a glucose culture might show a corresponding loss in hemotoxin titer.

Exper. 9. The Effect on Hemotoxin Production of Adjustment of the Reaction of Glucose and Serum Cultures.-Two flasks of $1 \%$ glucose broth and 2 flasks of $5 \%$ serum broth, each containing $25 \mathrm{c} \mathrm{c}$ of medium, were inoculated with $1.5 \mathrm{cc}$ each of a 12 -hour plain broth culture from pleural fluid 590 . Hemotoxin titrations and $P_{F}$ determinations were made after $4,6,8,10$, and 24 hours of growth. Flask 1 of glucose broth and flask 1 of serum broth were allowed to follow their natural course of acidity production. Flask 2 of glucose broth was adjusted in reaction at the hours mentioned to the $P_{H}$ of flask 1 of serum broth, while flask 2 of serum broth was adjusted to the $P_{H}$ of flask 1 of glucose broth. Adjustments were made by the addition of $\mathrm{HCl}$ and $\mathrm{NaOH}$. The results are recorded in table 5 .

TABLE 5

RESULTS OF EXPER. 9

\begin{tabular}{|c|c|c|c|c|c|c|c|c|c|c|}
\hline \multirow{3}{*}{$\begin{array}{l}\text { Period of } \\
\text { Growth }\end{array}$} & \multicolumn{5}{|c|}{ Glucose Broth Culture } & \multicolumn{5}{|c|}{ Serum Broth Culture } \\
\hline & \multicolumn{2}{|c|}{ Flask 1} & \multicolumn{3}{|c|}{ Flask 2} & \multicolumn{2}{|c|}{ Flask 1} & \multicolumn{3}{|c|}{ Flask 2} \\
\hline & $\begin{array}{c}\text { Hemo- } \\
\text { toxin }\end{array}$ & $\mathbf{P}_{\mathbf{H}}$ & $\begin{array}{c}\text { Hemo- } \\
\text { toxin }\end{array}$ & $P_{H}$ & $\begin{array}{c}\mathrm{P}_{H} \mathrm{Ad}- \\
\text { justed to }\end{array}$ & $\begin{array}{c}\text { Hemo- } \\
\text { toxin }\end{array}$ & $P_{\mathbf{H}}$ & $\begin{array}{c}\text { Hemo- } \\
\text { toxin }\end{array}$ & $P_{\mathrm{H}}$ & $\begin{array}{l}\mathrm{PH}_{\mathrm{Ad}} \\
\text { justed to }\end{array}$ \\
\hline $\begin{array}{l}\text { Before in- } \\
\text { oculation } \\
4 \text { hours } \\
6 \text { hours } \\
8 \text { hours } \\
10 \text { hours } \\
24 \text { hours }\end{array}$ & $\begin{array}{c}0 \\
++ \\
++ \\
++ \\
0 \\
0\end{array}$ & $\begin{array}{l}6.8 \\
5.5 \\
5.2 \\
5.2 \\
5.2 \\
5.0\end{array}$ & $\begin{array}{c}0 \\
++ \\
++ \\
++ \\
+ \\
0\end{array}$ & $\begin{array}{l}6.8 \\
5.5 \\
5.2 \\
5.2 \\
5.2 \\
5.2\end{array}$ & $\begin{array}{l}6.8 \\
6.8 \\
6.8 \\
7.0\end{array}$ & $\mid \begin{array}{c}0 \\
++++ \\
++++ \\
++++ \\
++++ \\
++++\end{array}$ & $\begin{array}{l}6.8 \\
6.8 \\
6.8 \\
6.8 \\
6.8 \\
6.5\end{array}$ & $\left|\begin{array}{c}0 \\
++++ \\
++++ \\
++++ \\
++++ \\
0\end{array}\right|$ & $\begin{array}{l}6.8 \\
6.8 \\
5.5 \\
5.5 \\
5.4 \\
\mathbf{5 . 4}\end{array}$ & $\begin{array}{l}5.5 \\
\text { No change made } \\
\text { No change made } \\
\text { No change made } \\
\text { No change made }\end{array}$ \\
\hline
\end{tabular}

The results of this experiment are not striking. No differences occur between flasks 1 and 2 of the glucose cultures until the tenth 
hour and not until after the tenth hour in the serum culture. The persistence of hemotoxin in the glucose culture, adjusted to the reaction of the serum culture, was only slightly greater than in the unadjusted culture. At no time did the hemotoxin production in the adjusted glucose culture equal that of the serum culture, and for the first 8 hours it did not exceed that of the unadjusted glucose.

In considering the lack of effect on hemotoxin production when the acidity of the glucose culture is neutralized by the addition of acid, note should be made of the rapid return to an acid reaction in the adjusted culture. It is probable that the effects of neutralization persisted for only a short time, as a subsequent experiment has shown that in a rapidly growing glucose culture a lowering of $P_{H}$ of 0.6 occurs in half an hour after adjustment and that repeated adjustment is followed each time by the same rapid increase in acidity. The conditions in the flask of glucose culture in which the reaction was adjusted were not very different, then, from those of the unadjusted flask and a marked effect on hemotoxin could not therefore be expected.

Observation of the hemotoxin titer of the serum broth culture, which was adjusted to the $P_{H}$ of the glucose broth culture, shows that hemotoxin is not destroyed, at least, and is perhaps still produced when exposed to a $P_{\mathrm{H}}$ of 5.5 during a period of 6 hours, that is, from the fourth to the tenth hour of growth. Comparisons should hardly be drawn, however, between the conditions in the flask of adjusted serum broth and the acidity produced by a growing culture, for the character of acid in the two is probably different, and as Lyall ${ }^{6}$ has suggested, the inhibiting action of the acids formed by the growth of bacteria in the presence of glucose may be qualitatively quite different from the effect exerted by $\mathrm{HCl} .{ }^{17}$

With this point in mind a similar experiment was carried out using lactic acid to lower the $P_{H}$ of the serum culture, as lactic acid is one of the degradation products of glucose.

Exper. 10. Further Observatins on the Effect of Adjustment of Reaction on Hemotoxin Production.-The procedure of exper. 9 was followed, except that a glucose serum culture was substituted for a plain glucose culture and lactic acid was used in place of $\mathrm{HCl}$. Pleural fluid 4 was the source of culture for inoculation (table 6).

The results of this experiment do not differ from those of the previous experiment. Repeated neutralization of the acidity of a

17 An investigation of the acids formed by glucose cultures of the streptococcus is now being made by $L$. F. Foster and $G$. Bernice Rhodes of this laboratory. 
glucose culture caused a somewhat longer persistence of hemotoxin than occurred in a culture in which the reaction was not adjusted. The difference was slight, however. The results with serum broth culture were the same as in exper. 9. Lactic acid produced no effects different from those obtained with $\mathrm{HCl}$. Both series of results indicate inhibition of hemotoxin production by acid.

TABLE 6

RESUlts of ExpEr. 10

\begin{tabular}{|c|c|c|c|c|c|c|c|c|c|}
\hline \multirow{3}{*}{$\begin{array}{l}\text { Period of } \\
\text { Growth }\end{array}$} & \multicolumn{4}{|c|}{ Glucose Serum Culture } & \multicolumn{5}{|c|}{ Serum Culture } \\
\hline & \multicolumn{2}{|c|}{ Flask 1} & \multirow{2}{*}{\multicolumn{2}{|c|}{$\frac{\text { Flask 2 }}{\underset{\text { toxin }}{\text { Hemo- }} \mid \begin{array}{c}\text { Pu Ad- } \\
\text { justed to }\end{array}}$}} & \multicolumn{2}{|c|}{ Flask 1} & \multicolumn{3}{|c|}{ Flask 2} \\
\hline & $\underset{\text { toxin }}{\text { Hemo- }}$ & $P_{H}$ & & & $\underset{\text { toxin }}{\text { Hemo- }}$ & $\mathbf{P}_{\mathbf{H}}$ & $\begin{array}{c}\text { Hemo- } \\
\text { toxin }\end{array}$ & $P_{H}$ & $\begin{array}{l}P_{H} \text { Ad- } \\
\text { justed to }\end{array}$ \\
\hline $\begin{array}{l}\text { Before in- } \\
\text { oculation } \\
3 \text { hours } \\
5 \text { hours } \\
7 \text { hours } \\
10 \text { hours } \\
12 \text { hours } \\
24 \text { hours }\end{array}$ & $\begin{array}{c}0 \\
++ \\
+++ \\
++++ \\
+++ \\
++ \\
0\end{array}$ & $\begin{array}{l}7.4 \\
7.1 \\
6.4 \\
5.7 \\
5.3 \\
5.4 \\
5.4\end{array}$ & $\begin{array}{c}0 \\
++ \\
+++ \\
++++ \\
+++ \pm \\
+++ \pm \\
\pm\end{array}$ & $\begin{array}{l}7.3 \\
7.0 \\
6.9 \\
6.9 \\
6.9\end{array}$ & $\begin{array}{c}0 \\
++++ \\
++++ \\
++++ \\
++++ \\
++++ \\
++++\end{array}$ & $\begin{array}{l}7.4 \\
7.35 \\
7.0 \\
6.9 \\
6.9 \\
6.8 \\
6.85\end{array}$ & $\begin{array}{c}0 \\
++++ \\
++++ \\
++++ \\
+++ \pm \\
++ \\
0\end{array}$ & $\begin{array}{l}7.4 \\
7.3 \\
6.8 \\
6.4 \\
5.6 \\
5.3 \\
5.4\end{array}$ & $\begin{array}{c}7.1 \\
6.4 \\
5.7 \\
5.3 \\
\text { No change made }\end{array}$ \\
\hline
\end{tabular}

The effect of acidity on hemotoxin production was further studied by determining whether a neutralized filtrate from a glucose culture, which had ceased to produce hemotoxin, would again become hemotoxic if reinoculated with a fresh culture. If hemotoxin could be produced in such a neutralized filtrate, but not in a similarly inoculated but unneutralized filtrate, evidence would be furnished that the acids are the most effective metabolic products in inhibiting hemotoxin production.

Exper. 19. Further Observations on the Effect of Adjustment of Reaction Culture.-A flask containing $200 \mathrm{cc}$ of a $1 \%$ glucose broth was inoculated with a 12-hour plain broth culture of pleural fluid 1088. Tests were made on this culture at intervals, and when hemotoxin was no longer demonstrable, the culture was filtered. A $P_{\mathbf{H}}$ determination was made on the filtrate, after which a $10 \mathrm{cc}$ portion was reserved without neutralization, while the remainder was neutralized with sterile $\mathrm{N} / 1 \mathrm{NaOH}$. Both portions were inoculated with $0.1 \mathrm{c} \mathrm{c}$ to every $10 \mathrm{cc}$ of a 12-hour plain broth culture of pleural fluid 1088 . After 6 to 8 hours' incubation tests were made as on the original culture. If lysis occurred, the filtrate culture was allowed to continue to grow until no hemotoxin was present. It was then filtered again. This procedure was repeated until a filtrate was obtained in which hemotoxin was not formed. In every case the $P_{1}$ to which the filtrates were adjusted was 7.6. A qualitative determination of glucose by means of Benedict's. test was made on the 
original broth and on each successive filtrate before inoculation to give a rough estimation of the utilization of sugar (table 7).

TABLE 7

The Effect of Neutralization on Hemotoxin Production in Filtrates of Glucose Cultures

\begin{tabular}{|c|c|c|c|c|c|}
\hline Culture in & Growth & $\begin{array}{l}\text { Test for } \\
\text { Glucose }\end{array}$ & $\underset{P_{n}}{\text { Final }}$ & $\underset{\text { sis }}{\text { Hemoly- }}$ & $\begin{array}{c}\text { Period of Persistence } \\
\text { of Hemotoxin }\end{array}$ \\
\hline $\begin{array}{l}\text { Original broth........... } \\
\text { Filtrate } 1\end{array}$ & ++++ & ++++ & 5.2 & ++ \pm & Between 10 and 12 hours \\
\hline $\begin{array}{l}\text { Unneutralized......... } \\
\text { Nentralized. }\end{array}$ & $\stackrel{ \pm}{ \pm+}$ & +++ & 5.05 & $\stackrel{ \pm}{ \pm+}$ & Between 3 and 6 hours \\
\hline 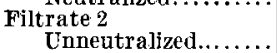 & 0 & $+t+$ & & 0 & \\
\hline $\begin{array}{l}\text { Neutralized...... } \\
\text { Filtrate } 3\end{array}$ & ++++ & +++ & 5.1 & ++++ & Between 9 and 24 hours \\
\hline 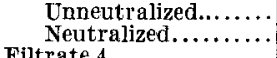 & $\begin{array}{c}0 \\
++++\end{array}$ & $\stackrel{ \pm}{ \pm}$ & $\dddot{6.85}$ & $\begin{array}{c}0 \\
++++\end{array}$ & Between 24 and 48 hours \\
\hline $\begin{array}{c}\text { Unneutralized......... } \\
\text { Neutralized.......... }\end{array}$ & $\begin{array}{c}0 \\
++\end{array}$ & $\begin{array}{l}0 \\
0\end{array}$ & 7.4 & $\begin{array}{c}0 \\
++\end{array}$ & Between 6 and 24 hours \\
\hline 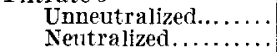 & $\begin{array}{c}0 \\
+\end{array}$ & $\begin{array}{l}\text { Not done } \\
\text { Not done }\end{array}$ & 7.4 & $\begin{array}{c}0 \\
+++\end{array}$ & Between 6 and 24 hours \\
\hline
\end{tabular}

* The test for glucose was made in each case before inoculation.

These results show that while hemotoxin was not produced in unneutralized portions of the filtrate from a glucose culture, with the exception of a slight amount of hemotoxin in the first filtrate, the neutralized filtrate becomes an excellent medium for hemotoxin production when reinoculated with a fresh culture. Not only is the first filtrate capable of furnishing material for hemotoxin production, but the second and third filtrates are equally efficacious. In fact, as the glucose was progressively removed from each successive filtrate, hemotoxin production increased over that in the original broth up to the fourth filtrate. Growth of the organism was likewise rapid in the first 3 filtrates. In the fourth and fifth filtrates both growth and hemotoxin production decreased. From these data one may conclude that of the metabolic products the acids are most active in inhibiting hemotoxin production. It is probable that with the rapid utilization of the glucose in the medium, the degradation products from the sugar form the greater part of all the products of metabolism, since the proteins are undoubtedly spared at the expense of the glucose. As long as glucose is present in the medium, the metabolic products chiefly responsible for inhibition of hemotoxin are the acids formed. With the continued utilization of glucose up to a point of disappearance, other elements of the medium must be called on to supply the growth and energy 
requirements of the organism. After this period the nature of the metabolic products must change. As no efforts were made to remove any of the cleavage substances, other than acids, a gradual accumulation of all other products of metabolism must have been made with each successive filtrate. From observation of table 7 it would appear that such an accumulation, slight during the cleavage of glucose, exerted an appreciable influence in the fourth and fifth filtrates, since growth became less active and the length and intensity of production of hemotoxin decreased considerably.

This experiment indicates that in a glucose culture, the metabolic products responsible for the inhibition of hemotoxin production are the acids. With the elimination of glucose, there is probably an increased utilization of the protein constituents of the medium with the formation of nitrogenous degradation products. Sufficient accumulation of these substances also exerts an inhibiting action on hemotoxin production. In the usual tests on hemotoxin production in a $1 \%$ culture, however, the action of the nitrogenous degradation products must be almost negligible, as hemotoxin production ceases before sufficient glucose has been removed from the medium to permit an increase in the protein metabolsm.

To summarize the results of the three types of experiment, acidity must be considered a most important factor in the inhibition of hemotoxin, since (1) continuous neutralization of the acids formed through the use of phosphates prolongs the period of production of hemotoxin; (2) frequently repeated, but not continuous, neutralization exerts a slightly favorable effect on hemotoxin production, while the addition of hydrochloric and lactic acids to a serum culture decreases the period of hemotoxin production, and (3) neutralization of the acidity of a filtrate from a glucose culture restores to the medium its hemotoxin producing properties, while hemotoxin is not obtained from an unneutralized portion. However, although acidity has a great influence on the inhibition of hemotoxin production in glucose cultures, it is probably not the only contributing factor. The fact that in two tubes, having the same hydrogen-ion concentration, there may be different quantities of hemotoxin produced is evidence that other forces also exert an influence. The rate of growth is unquestionably of importance. During the course of all experiments in which glucose cultures were used, it was repeatedly noted that a rapidly growing culture with a $P_{H}$ lower than that of a culture in which growth was not so ltxxuriant 
had, nevertheless, a higher hemotoxin titer. A study was therefore made of the relationship of the rate of growth to hemotoxin production in glucose cultures.

\section{THE EFFECT OF RATE OF GROWTH ON HEMOTOXIN PRODUCTION}

\section{IN GLUCOSE CULTURES}

The view is uniformly held by investigators who have studied the question of hemotoxin production that in mediums of uniform and constant composition the concentration of hemotoxin is to a large extent dependent on the rapidity of multiplication of organisms. Besredka ${ }^{2}$ states that the potency of a hemotoxin depends on the abundance of growth. M'Leod ${ }^{3}$ found that hemolysin production increased with the rapidity of multiplication. Sachs, ${ }^{16}$ Pribram, ${ }^{18}$ Rieke, ${ }^{19}$ and Lyall ${ }^{6}$ express similar views-that hemotoxin production is a function of the increasing and multiplying organism and that maximum amounts are produced by young, active cultures. Closely connected with the rapidity of growth is the amount of inoculum used. This question is of particular importance to hemotoxin production in glucose cultures, for hemotoxin is formed in the early periods of growth only, and any factor that diminishes the lag of a culture will presumably have a direct influence on the formation of hemotoxin. Rieke $^{19}$ and Lyall ${ }^{6}$ found considerable differences in the hemotoxin production of cultures in the same medium which were inoculated with different amounts. In cultures inoculated heavily, when growth was initiated with practically no lag, hemotoxin appeared earlier and in higher concentration than in cultures lightly inoculated. In our preliminary experiments certain variations in the production of hemotoxin in glucose cultures can probably be ascribed in part at least to differences in the amount of inoculum. This question is considered in detail in the following experiment.

Exper. 12. The Relation Between the Rate of Growth and Hemotoxin Production in a Glucose Medium.-Two tubes containing $1 \%$ glucose broth were inoculated, the first with $3 \mathrm{cc}$ of a 16-hour plain broth culture from pleural fluid 4 and the second with $0.3 \mathrm{cc}$ of the same culture. Both tubes after inoculation contained the same amount of material-20 $\mathrm{cc}$. Hemolysis tests, counts by the plating method, and $P_{\mathrm{H}}$ determinations were made after 4,7 and 10-hour periods of growth (table 8).

This experiment was repeated a number of times and in every case the same relationship was found to exist between growth and hemotoxin production.

18 Handbuch der Path. Migroorganismen, 1913, 2, p. 1328.

10 Centralbl. f. Bakteriol., O., I, 1904, 36, p. 321. 
A number of interesting points are brought out by a study of these results. In the heavily inoculated tube, in spite of a rapid lowering of $P_{H}$ hemotoxin production proceeded for a time at a rate almost parallel with the rate of growth. At 4 hours there was a high titer of hemotoxin in this culture while in the lightly inoculated culture there was no hemotoxin. At the seventh hour the hemotoxin titer of the two cultures was particularly interesting.

TABLE 8

The Relation Between Rate of Growth and Hemotoxin Production

\begin{tabular}{|c|c|c|c|c|c|c|}
\hline \multirow[b]{2}{*}{ Age of Culture } & \multicolumn{3}{|c|}{ Tube Inoculated With 3.0 e c Oulture } & \multicolumn{3}{|c|}{ Tube Inoculated With $0.3 \mathrm{c}$ c Culture } \\
\hline & Hemotoxin & $\begin{array}{l}\text { Count- } \\
\text { Millions per } \\
\text { C.mm. }\end{array}$ & $\mathbf{P}_{\mathbf{H}}$ & Hemotoxin & $\begin{array}{l}\text { Count-- } \\
\text { Millions per } \\
\text { C.mm. }\end{array}$ & $\mathbf{P}_{\boldsymbol{H}}$ \\
\hline $\begin{array}{l}0 \text { hours } \\
4 \text { hours } \\
7 \text { hours } \\
10 \text { hours }\end{array}$ & $\begin{array}{c}0 \\
++++ \\
+++ \\
0\end{array}$ & $\begin{array}{c}1.162 \\
1167.0 \\
80,000.0\end{array}$ & $\begin{array}{l}7.6 \\
6.0 \\
5.6 \\
5.2\end{array}$ & $\begin{array}{c}0 \\
0 \\
++ \\
+\end{array}$ & $\begin{array}{r}0.9 \\
1.2 \\
710.0\end{array}$ & $\begin{array}{l}7.6 \\
6.8 \\
6.4 \\
5.6\end{array}$ \\
\hline
\end{tabular}

In the heavily inoculated culture with a count of 1,167 million per c. mm., hemotoxin was present in the concentration of +++ , although the $P_{H}$ was 5.6. In the lightly inoculated culture when the $P_{H}$ was 6.4 , but when the number of organisms was approximately equal to those giving a ++++ hemotoxin titer at the fourth hour in the heavily inoculated culture, the titer was only ++ . Moreover, this was the point of maximum production by this culture, since at the tenth hour the titer had decreased to + although the actual number of organisms was still increasing. From these data, it would appear that in a glucose culture the presence or lack of lag and the rapidity of multiplication regulate to some extent the production of hemotoxin. In a steadily but slowly increasing culture only slight amounts of hemotoxin are formed. Probably in all cultures we are concerned with the interaction of opposing forces. In the heavily inoculated culture the factors favoring hemotoxin production, namely, the rapid rate of multiplication of organisms, outweigh the inhibitory influence of glucose, while in the lightly inoculated culture the rate of growth is not sufficiently rapid at any time to overcome the forces acting simultaneously to inhibit. Even in the heavily inoculated culture, however, the rate of growth is not sufficient to maintain a high degree of hemotoxin production, for at the seventh hour when the organisms are still actively multiplying, the hemotoxin titer decreases and at the 
tenth hour has entirely disappeared. One may conclude that the rate of growth has a direct influence on hemotoxin production, but as growth is only one of several factors operating it is not possible to show the exact relationship existing between the two.

\section{THE EFFECT OF VIRULENCE ON HEMOTOXIN PRODUCTION}

As the rate of growth of a culture of streptococcus in a glucose medium is of so much importance to the production of hemotoxin, the question of the relation of virulence to hemotoxin production was suggested. A comparison of the results obtained in expers. 1 and 2 shows that a culture of the Holden strain, which had not been passed through animals, differed in hemotoxic properties from the same strain after repeated passage through the pleura of rabbits. The first, or laboratory, strain never produced hemotoxin in a glucose broth culture, while the passage strain usually was hemotoxic during the early period of growth on glucose. As the animals used for maintaining the virulence of the culture were rabbits and as the corpuscles used in all hemolytic tests were rabbit corpuscles, it seemed possible that the difference between the laboratory culture and the passage culture might be due to a specific increase in virulence for rabbit corpuscles, which would not be effective with corpuscles of other animals. A test was accordingly made to show the comparative activities of the laboratory and passage cultures on various corpuscles.

Exper. 13. A Comparison of the Hemotoxic Action of Laboratory and Passage Cultures on Corpuscles of Different Sources.-From a serum-broth culture of the laboratory strain and from pleural fluid 204, subcultures were made in plain and serum broths. On 10-hour growths of these cultures, hemotoxin titrations were made, using in 4 series of tests, rabbit, sheep, guinea-pig, and human corpuscles. The results were:

\begin{tabular}{|c|c|c|c|c|}
\hline o & Rabbit & Sheep & Guinea-Pig & Human \\
\hline $\begin{array}{l}\text { Laboratory strain in plain broth.............. } \\
\text { Laboratory strain in serum broth............ }\end{array}$ & $\begin{array}{l}+++ \\
++++\end{array}$ & $\begin{array}{l}+++ \\
++++\end{array}$ & $\stackrel{++}{++}+$ & $\stackrel{ \pm}{++}$ \\
\hline 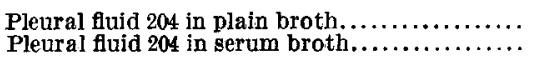 & $\begin{array}{l}++++ \\
++++\end{array}$ & $\begin{array}{l}++++ \\
++++\end{array}$ & $\begin{array}{l}+++ \\
++++\end{array}$ & $\begin{array}{l}+++ \\
+++\end{array}$ \\
\hline
\end{tabular}

Evidently the passage strain is somewhat more hemotoxic for all kinds of corpuscles than the laboratory strain. Both strains act more readily on rabbit and sheep than on human and guinea-pig corpuscles. As the comparative differences are the same in both cultures, however, they can hardly be ascribed to a selective virulence for rabbit corpuscles. 
The differences between the laboratory strain and the passage strain, as evidenced by the lack of hemotoxin production in glucose broth by the laboratory strain and the ability to produce hemotoxin in this medium by the passage strain, must depend, therefore, on factors other than a specific increase in activity for rabbit corpuscles. It is possible that these differences are due to changed properties of growth through cultivation on artificial medium on the one hand and actual experimental infection on the other. One would expect that such differences would be manifest in some phase of the metabolism of the two organisms, such as a variation in the utilization of protein, or in the fermentative properties. To determine whether this is the case, various phases of the metabolism of the two strains were investigated. As a means of orientation in a preliminary experiment in which mediums containing a number of carbohydrates and alcohols were used, the hemotoxic and fermentative activities of the two strains were compared. In a further experiment, using glucose medium only, quantitative determinations of protein and carbohydrate metabolism were made. These experiments follow.

Exper. 14. A Comparison of the Hemotoxic and Fermentative Activities of the Laboratory and Passage Strains in Mediums Containing Various Carbohydrates and Alcohols. - Mediums containing 1\% glucose, levulose, lactose, salicin, glycerol, and mannitol, and also plain and serum broth, were inoculated with proportionate amounts of plain broth cultures of the laboratory strain and pleural fluid 204. $\mathrm{P}_{\mathrm{H}}$ determinations and hemotoxin titrations were made at the time of inoculation and at 4, 8, 14, and 24 hours of growth (tables 9 and 10).

It is evident that the laboratory strain possesses much less hemotoxic activity than the passage strain. In the serum and mannitol cultures, only, was the degree of hemotoxin production equal to that of the passage strain. The inhibiting action of sugars on the laboratory strain was complete in every instance but one (14-hour growth in lactose), while hemotoxin was formed to some extent in all cultures of the passage strain. In general, acid formation was less rapid in the laboratory strain than in the passage strain. The lack of hemotoxin production with this strain in the presence of fermented sugars was not due, then, to a greater concentration of acids.

Exper. 15. A Comparative Study of the Metabolism of the Laboratory and Passage Strains.-Of 3 flasks, each containing $200 \mathrm{cc}$ of $1 \%$ glucose broth, the first was inoculated with $10 \mathrm{cc}$ of an 18-hour plain broth culture of the laboratory strain, the second with $10 \mathrm{c}$ c of an 18-hour plain broth culture of 

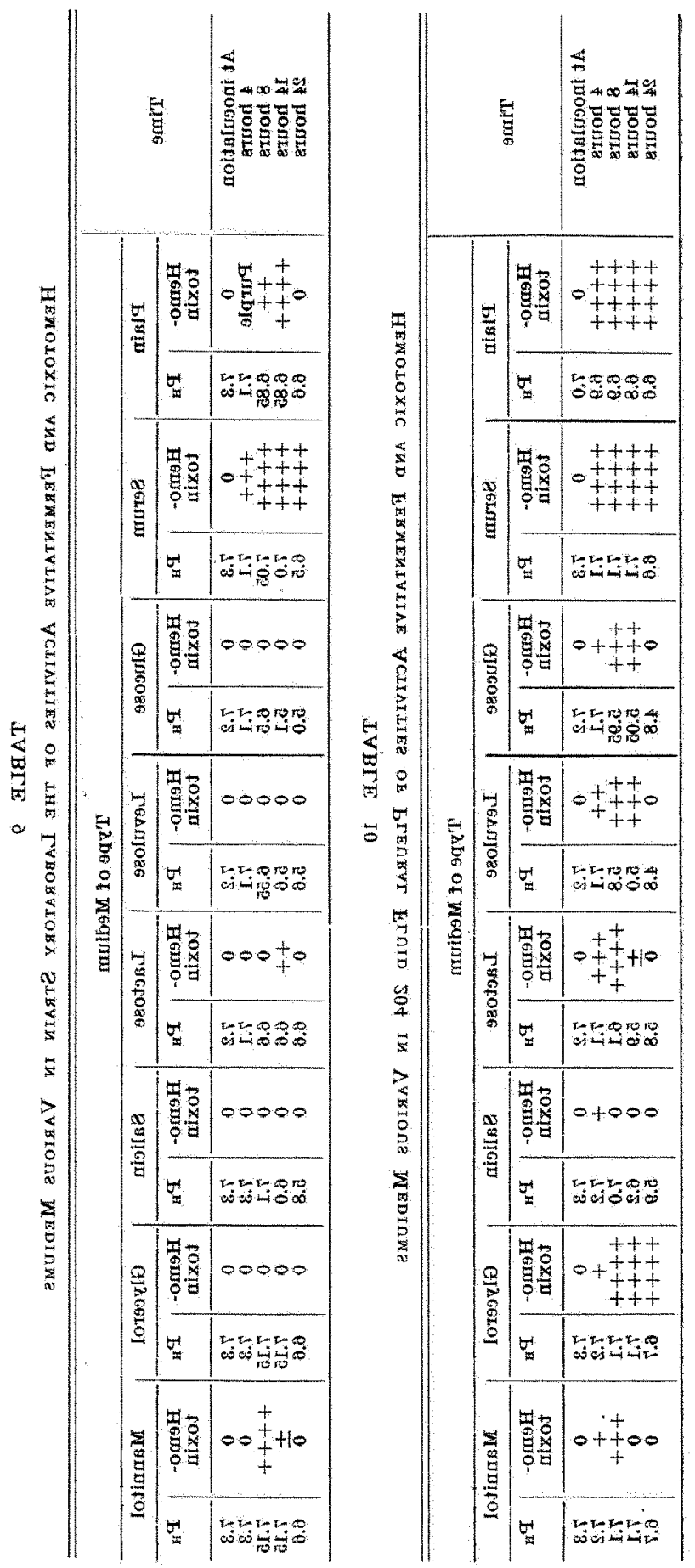

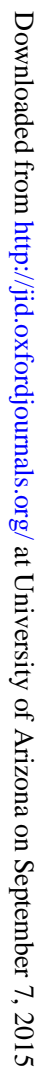


pleural fluid 19, and to the third, which served as a control, $10 \mathrm{cc}$ of sterile plain broth was added. The flasks were incubated. Fifty $\mathrm{cc}$ portions of medium were removed from each flask immediately after inoculation and at periods of 6 and 24 hours of growth, for determinations on the number of organisms, the $\mathrm{P}_{\mathrm{H}}$, the hemotoxin titer, glucose utilization and ammonia production. Wright's method of counting was used. The hemotoxin titrations and $\mathrm{P}_{\mathrm{H}}$ determinations were made in the usual way. The utilization of glucose was measured by determining the quantity of glucose present in the medium at each period of growth, the loss from time to time representing the amount of sugar utilized. Bertrand's procedure for the determination of glucose was used. For this test a preliminary clarification of the culture to remove peptones was necessary, since peptones interfere with the reduction test. The broth was clarified as follows:

Twenty $\mathrm{c} c$ of culture was diluted 1:5 with distilled water to make a total of $100 \mathrm{cc}$. To this, $20 \mathrm{cc}$ of a saturated aqueous solution of tannic acid was added. The precipitate which formed was removed by filtration. To the filtrate was added sufficient dry lead acetate to precipitate the tannic acid. This was again filtered and the excess lead acetate in the resulting filtrate was precipitated by the addition of dry sodium oxalate. On removal of this precipitate by filtration, a clear fluid was obtained which was peptone-free and was suitable for use in determining the amount of glucose in the culture under examination.

TABLE 11

Tests on the Metabolism of the Laboratory and Passage Strains

\begin{tabular}{|c|c|c|c|c|c|c|c|}
\hline \multirow[b]{2}{*}{ Time } & \multirow[b]{2}{*}{$\begin{array}{l}\text { Hemo- } \\
\text { toxin } \\
\text { Titer }\end{array}$} & \multirow[b]{2}{*}{$\begin{array}{c}\text { Count } \\
\text { per } \\
\text { C.mm. }\end{array}$} & \multirow[b]{2}{*}{$P_{\mathrm{H}}$} & \multicolumn{2}{|c|}{ Glucose } & \multicolumn{2}{|c|}{$\mathrm{NH}_{3}$ as } \\
\hline & & & & $\begin{array}{c}\text { Gm. } \\
\text { per } \\
100 \mathrm{C} \mathrm{e}\end{array}$ & $\begin{array}{c}\text { Total } \\
\text { Mg. } \\
\text { Utilized }\end{array}$ & $\begin{array}{l}\text { Mg. N } \\
\text { per } \\
100 \mathrm{Ce}\end{array}$ & $\begin{array}{c}\text { Total } \\
\text { Mg. N } \\
\text { Inerease }\end{array}$ \\
\hline $\begin{array}{c}\text { Laboratory Strain } \\
0 \text { hours } \\
6 \text { hours } \\
24 \text { hours } \\
\text { Pleural Fluid 19 } \\
0 \text { hours } \\
6 \text { hours } \\
24 \text { hours } \\
\text { Uninoculated Con- } \\
\text { trol } 0 \text { hours } \\
6 \text { hours } \\
24 \text { hours }\end{array}$ & $\begin{array}{c}0 \\
0 \\
0 \\
\\
0 \\
++ \\
0 \\
0 \\
0 \\
0 \\
0\end{array}$ & $\begin{array}{r}19,200 \\
800,900 \\
1,125,500 \\
\\
26,400 \\
1,159,660 \\
2,187,500\end{array}$ & $\begin{array}{l}7.8 \\
5.9 \\
5.35\end{array}$ & $\begin{array}{l}0.902 \\
0.845 \\
0.772 \\
0.927 \\
0.804 \\
0.767\end{array}$ & $\begin{array}{l}\cdots \\
\cdots\end{array}$ & $\begin{array}{l}5.054 \\
6.580 \\
6.510 \\
\\
7.00 \\
7.196 \\
8.288 \\
5.53 \\
5.19^{\circ}\end{array}$ & $\begin{array}{l}1.526 \\
1.456\end{array}$ \\
\hline
\end{tabular}

Ammonia determinations were made according to the method of Kendall, Day, and Walker of the Northwestern University Medical School:

To $2 \mathrm{cc}$ of broth culture were added $2 \mathrm{cc}$ of a $5 \%$ solution of sodium oxalate containing sodium carbonate and $1 \mathrm{cc}$ of hydrocarbon oil. Air washed in acid was forced through this mixture, slowly for the first 5 minutes, rapidly for the next 15 minutes. The ammonia liberated was eollected in a measured amount of $\mathrm{N} / 50 \mathrm{HCl}(5 \mathrm{cc})$. Titration of the unneutralized acid was made with $\mathrm{N} / 50 \mathrm{NaOH}$, using alizarin as indicator. Calculation of the $\mathrm{NH}_{3}$ nitrogen was then made.

The results are given in table 11. A repetition of this experiment gave similar results. 
The results of this experiment corroborate all the earlier observations on the differences in the ability of the two strains to produce hemotoxin in glucose medium. The passage strain gave a +++ titer of hemotoxin after 6 hours' growth, while no hemotoxin was produced at any time by the laboratory strain. This difference is paralleled to a certain extent by differences in other metabolic activities. During the first 6 hours-that is, during the period of hemotoxin production by the passage strain - this strain showed a greater rate of growth, a more marked acidity production, and a greater utilization of glucose than the laboratory strain. The difference in $\mathrm{NH}_{3}$ nitrogen was not marked. Nevertheless, larger amounts were produced by the laboratory than by the passage strain during the first six hours. This would be expected in view of the greater utilization of glucose by the passage strain during this period. At 24 hours the 2 strains more nearly approached each other in all phases of their metabolism.

The points of especial interest brought out by this experiment are that hemotoxin was formed most actively by the passage strain during the period of most rapid utilization of glucose and the greatest production of acid. If the inhibition of hemotoxin production by glucose were due to a protein sparing action, as suggested by Kuhn ${ }^{14}$ and Stevens and Koser, ${ }^{12}$ one would expect that hemotoxin would not be formed during this period. The results do not confirm this assumption. Evidently, it is not the utilization of glucose alone which interferes with hemotoxin production. A further contribution to the question of the relationship of acidity to hemotoxin production is also furnished by this experiment, since the passage strain gave a positive hemotoxic test at a time when the $P_{\mathrm{H}}$ was considerably lower than that of the laboratory strain.

Since the only explanation suggested by these results in regard to the differences in the hemotoxic activities of the laboratory and passage strains in the presence of glucose was the more rapid rate of metabolism of the passage strain in the early period of growth, it was considered of interest to determine whether the laboratory strain, which is known to produce hemotoxin in the presence of glucose if serum is also present in the medium, would approach the passage strain in other phases of metabolism when grown on glucose serum medium. Determinations were therefore made of the carbohydrate and protein metabolism of the laboratory and passage strains when grown on glucose serum broth. 
Exper. 16. Further Comparative Studies of the Metabolism of the Laboratory and Passage Strains.-A procedure was employed similar to that of exper. 15. The medium used contained in addition to $1 \%$ of glucose, $5 \%$ of horse serum. The pleural fluid in this case was 198. A further measurement of metabolism was made by determining the amino acid content of the cultures by means of formol titrations. These titrations were performed according to the method employed by Kendall, Day and Walker. The procedure was as follows :

To $50 \mathrm{cc}$ of distilled water were added $5 \mathrm{cc}$ of a broth culture and $1 \mathrm{cc}$ of phenolphthalein. This was titrated to neutrality with $\mathrm{N} / 10 \mathrm{NaOH}$. Five c c of neutral formaldehyd were added, and the mixture titrated again. The amino acid content was determined from the last figure according to the equation R.CH.NH$H_{2}+\mathrm{HCOH} \rightleftarrows$ R.CH.N.CH $\mathrm{CH}_{2}+\mathrm{H}_{2} \mathrm{O}$.<smiles>CCC(=O)O</smiles>

\section{$\mathrm{COOH}$}

All determinations were made at the time of inoculation and at $3,6,9$, and 12 hour periods of growth (table 12).

TABLE 12

Metabolism of Laboratory and Passage Strains

\begin{tabular}{|c|c|c|c|c|c|c|c|}
\hline \multirow[b]{2}{*}{ Time } & \multirow[b]{2}{*}{$\begin{array}{c}\text { Hemo- } \\
\text { toxin } \\
\text { Titer }\end{array}$} & \multirow[b]{2}{*}{$\begin{array}{l}\text { Count } \\
\text { per } \\
\text { c.mm. }\end{array}$} & \multirow[b]{2}{*}{$P_{\mathbf{H}}$} & \multicolumn{2}{|c|}{ Glucose } & \multirow{2}{*}{$\begin{array}{l}\mathrm{NHz} \text { as } \\
\mathrm{Mg} . \mathrm{N} \\
\text { per } \\
100 \mathrm{Oe}\end{array}$} & \multirow{2}{*}{$\begin{array}{l}\text { Amino } \\
\text { Acids as } \\
\text { Mg. N } \\
\text { per } \\
100 \mathrm{C} \mathrm{c}\end{array}$} \\
\hline & & & & $\begin{array}{c}\mathrm{Gm} . \\
\text { per } \\
100 \mathrm{C} \mathrm{c}\end{array}$ & $\begin{array}{c}\text { Total } \\
\text { Mg. } \\
\text { Utilized }\end{array}$ & & \\
\hline $\begin{array}{c}\text { Laboratory Strain } \\
0 \text { hours } \\
3 \text { hours } \\
6 \text { hours } \\
9 \text { hours } \\
12 \text { hours } \\
\text { Pleural Fluid } 198\end{array}$ & $\begin{array}{c}0 \\
0 \\
++++ \\
++++ \\
0\end{array}$ & $\begin{array}{r}40,000 \\
90,400 \\
1,456,000 \\
2,860,000 \\
4,700,000\end{array}$ & $\begin{array}{l}7.35 \\
7.20 \\
5.90 \\
4.95 \\
4.90\end{array}$ & $\begin{array}{l}0.992 \\
1.001 \\
0.862 \\
0.722 \\
0.728\end{array}$ & $\begin{array}{l}\cdots \\
130 \\
270 \\
262\end{array}$ & $\begin{array}{l}6.43 \\
5.45 \\
8.67 \\
8.25 \\
7.69\end{array}$ & $\begin{array}{l}19.17 \\
20.95 \\
18.03 \\
20.55 \\
20.61\end{array}$ \\
\hline $\begin{array}{r}0 \text { hours } \\
3 \text { hours } \\
6 \text { hours } \\
9 \text { hours } \\
12 \text { hours }\end{array}$ & $\begin{array}{c}0 \\
0 \\
++++ \\
++++ \\
0\end{array}$ & $\begin{array}{r}23,800 \\
90,200 \\
2,000,000 \\
3,500,000 \\
4,560,000\end{array}$ & $\begin{array}{l}7.35 \\
7.20 \\
5.80 \\
5.10 \\
4.90\end{array}$ & $\begin{array}{l}1.096 \\
1.068 \\
0.941 \\
0.877 \\
0.847\end{array}$ & $\begin{array}{r}28 \\
28 \\
155 \\
219 \\
249\end{array}$ & $\begin{array}{r}5.03 \\
6.29 \\
9.93 \\
10.49 \\
10.07\end{array}$ & $\begin{array}{l}19.77 \\
18.21 \\
16.87 \\
19.41 \\
20.73\end{array}$ \\
\hline
\end{tabular}

The results of this experiment show a much greater similarity between the 2 strains in serum glucose broth than in plain glucose broth. Both produced hemotoxin in the same concentration and at the same period of growth. The rates of growth and acidity production ran closely parallel. The passage culture used somewhat less glucose and produced somewhat greater amounts of $\mathrm{NH}_{3}$ nitrogen than the laboratory strain, but the differences were not marked. The values obtained for amino acid nitrogen show a similarity between the 2 strains, in that both reached a low point at 6 hours, followed by a subsequent increase.

A consideration of the results of this experiment, together with those of exper. 15, brings out several important points. First, when the various phases of the metabolism of the laboratory and passage 
strains are practically the same, there are no differences in hemotoxin production. Second, when the two strains are grown in plain glucose broth, a medium on which the rate of growth and other metabolic activities of the two strains differ, hemotoxin production occurs only in the strain which shows the greater rate of metabolism. When, by changing the conditions of growth of the laboratory strain, its metabolism is increased in every respect-that is, in rate of growth, acidity production, glucose utilization, and the production of $\mathrm{NH}_{3}$ nitrogen, it becomes capable of producing hemotoxin in the presence of glucose. From these results it is evident that the ability to produce hemotoxin in a glucose medium cannot be based on any one phase of metabolism, since an increase in hemotoxic activity occurs simultaneously with an increase in all other types of metabolism. Certainly the hemotoxic action of the laboratory strain in exper. 16 cannot be due to the greater utilization of glucose and increased acidity production. It is probable, rather, that in the cultures in which hemotoxin was produced, a factor was operating which acted to form hemotoxin in spite of the increased carbohydrate metabolism. This factor can be described only as an increased vitality of the organism. Further evidence that hemotoxin production is closely related to the vitality of the organism is furnished by the fact that hemotoxin occurs in every case immediately following the period of greatest activity of the culture as measured by determinations of all types of metabolism.

The only explanation of the relationship between virulence and hemotoxin production given by these experiments is the general tendency for the passage strain to show greater activity than the laboratory strain in all phases of its metabolism. No one function is particularly emphasized. In regard to this question, Rosenthal and Patai ${ }^{20}$ report similar results, except that in determinations of the metabolism of virulent and avirulent strains, these authors obtained a greater cleavage of amino acids by virulent than by avirulent strains. An insufficient number of formol titrations was made in the present work to draw any conclusions on this point.

\section{CONCLUSIONS}

This is a study on the hemotoxic and other metabolic properties of a single strain of human Streptococcus pyogenes (Holman) grown under two conditions: (1) artificial medium since isolation (laboratory

${ }^{20}$ Centralbl. f. Bakteriol., O., I, 1914, 73, p. 406. 
strain) ; (2) the same passed repeatedly through the pleura of rabbits (passage strain). The following conclusions may be drawn:

There is a distinct difference in the hemotoxic properties of the laboratory and passage strains.

This difference is not due to differences in the rate of multiplication alone.

The inhibition of hemotoxin production in the laboratory strain as contrasted with the hemotoxic activity of the passage strain cannot be ascribed to a greater acidity production by the laboratory strain.

The inhibition of hemotoxin production in the laboratory strain cannot be ascribed to a greater protein sparing action as evidenced by a greater utilization of glucose.

The types of protein metabolism of the two strains are not sufficiently dissimilar to serve as an index to differences in hemotoxin production.

The production of hemotoxin by the laboratory strain in a glucose serum culture, as contrasted by lack of hemotoxin production in a glucose culture, cannot be ascribed to any one difference in metabolism, which was measured by the methods used above.

The only factor that can be said definitely to favor hemotoxin production is increased vitality of the organism.

The question of hemotoxin production remains a complicated one. A summary of the entire study indicates only that hemotoxin production is due to, and controled by, conditions that influence growth. As such conditions can be studied only as a complex of interacting forces with no possibility of observing the action of a single variant, it is not possible to state the exact relationship between any one phase of metabolism and hemotoxin production. One can conclude only that hemotoxin production is an expression of the summation of activities of the organism and is capable of varying with every variation of environment and nutrition. 